\title{
A new name and a new synonym in Miconia (Melastomataceae)
}

\author{
Susanne S. Renner', Renato Goldenberg ${ }^{2}$ \\ I Herbaria and University of Munich, Menzingerstr. 67, Munich, Germany 2 Departamento de Botânica, \\ Universidade Federal do Paraná, 81531-970, Curitiba, Paraná, Brazil \\ Corresponding author: Susanne Renner (renner@lrz.uni-muenchen.de)
}

Academic editor: Hanno Schaefer | Received 24 February 2011 | Accepted 7 April 2011 | Published 30 May 2011

Citation: Renner SS, Goldenberg R (2011) A new name and a new synonym in Miconia (Melastomataceae). PhytoKeys 3: 35-37. doi: 10.3897/phytokeys.3.1174

\begin{abstract}
The name Miconia densiflora Cogn. (1886) is a later homonym of M. densiflora (Gardner) Naudin (1851), but since we propose it as a taxonomic synonym of $M$. caudata (Bonpl.) DC. (1828), we do not provide a new name. The name Miconia longicuspis Herzog (1909) is a later homonym of M. longicuspis Cogn. (1891) and we here propose its replacement by M. longicuspidata S.S. Renner \& R. Goldenb.
\end{abstract}

\section{Keywords}

Bolivia, Colombia, Melastomataceae, Miconia, homonyms, synonyms, taxonomy

\section{Introduction}

The site Melastomataceae.net provides a portal to open-access databases dealing with Melastomataceae, a pan-tropical family of about 3500 species. Among the databases that can be accessed at this site is "MEL names," which deals with the ca. 13,278 names of Melastomataceae and Memecylaceae (= Melastomataceae subfamily Olisbeoideae) and provides information on recognized species, synonyms, and relevant literature. In the course of dealing with the 1497 names available for Miconia Ruiz \& Pav., a genus of at least 1061 accepted species, we discovered two homonymy problems, resolved here. Since one of the homonyms is actually a heterotypic synonym of another species, a replacement name is only needed for one of these species. A comprehensive taxonomic treatment of Miconia is currently in preparation, as part of the PBI Miconieae project (sweetgum.nybg.org/melastomataceae/). 


\section{Systematics}

Miconia longicuspidata S.S.Renner \& R.Goldenb., nom. nov. urn:Isid:ipni.org:names:77111574-1

http://species-id.net/wiki/Miconia_longicuspidata

Replaced name: Miconia longicuspis Herzog, Feddes Repert. Nov. Sp. 7: 64. 1909. TYPE: BOLIVIA. Cordillera de Santa Cruz: Cerro Amboró, Cuñucú, 600-1400 m, Oct 1907, T.Herzog 326 (holotype: Z!). Not Miconia longicuspis Cogn. in A.DC. \& C.DC, Monog. Phan. 7: 850. 1891.

Comments. Miconia longicuspis Herzog is a later homonym of Miconia longicuspis Cogn., a treelet from eastern Brazil (Goldenberg and Reginato 2006). Miconia longicuspidata is known only from the holotype at Z, a collection by Theodor Herzog (1880-1961) in the mountains of Cunucú, Bolivia, in 1907. We have found no isotypes or type photos in G, JE, L, U, W, or WAG. This species most closely matches M. abbreviata Markgr., a widespread shrub that ranges from Bolivia throughout the Amazon basin to the Guianas, but differs in the much denser secondary venation. In $M$. abbreviata the secondaries are spaced at about $0.5-0.7 \mathrm{~mm}$ apart, in $M$. longicuspidata, only 2-3 mm apart. Theodor Herzog was an expert mountaineer and collector, who explored widely in Bolivia. During his two expeditions to that country in 1907/08 and 1910/11, he collected about 600 species of vascular plants. In 1910, Herzog not only explored the Cordillera Santa Cruz, where M. longicuspidata appears to be endemic, but also surveyed the Cordillera de Cocapata, a range of peaks near Cochabamba extending northwest for about 100 kilometers. A description of the flora of the Cordillera de Santa Cruz is given in Herzog (1910). A color photograph of the type is available at http://www.zuerich-herbarien.uzh.ch.

Miconia caudata (Bonpl.) DC., Prodr. 3: 187. 1828.

http://species-id.net/wiki/Miconia_caudata

Basionym: Melastoma caudata Bonpl., Monogr. Melast. 1: 13. t. 7. 1807.

New synonym: Miconia densiflora Cogn., Bot. Jahrb. 8(1): 22, 1887 [1886]; et in A. DC. \& C. DC. Monog. Phan. 7: 744, 1891, syn. nov. TYPE: COLOMBIA. Cauca: Popayan, Apr 1883, Lehmann 2798 (Isotype: US!). Non Miconia densiflora (Gardner) Naudin, Ann. Sc. Nat. Ser. 3, 16: 245, 1851, basionym Chaenopleura densiflora Gardner, Hook. Lond. Journ. Bot. 2: 349, 1843.

Comments. Miconia densiflora Cogn. is a later homonym of Miconia densiflora (Gardner) Naudin, which in turn is a taxonomic synonym of Miconia pusilliflora (DC.) Triana, a shrub from eastern Brazil (Cogniaux 1891; Goldenberg 2000). By contrast, Cogniaux' $M$. densiflora is based on a collection made by Lehmann near Popayán, in 
the State of Cauca, Colombia, in 1883 . The name is undoubtedly a taxonomic synonym of the common and frequently collected Miconia caudata (Bonpl.) DC. Cogniaux (1891: 736, 739) erroneously states that $M$. caudata has glandular-pubescent filaments, while $M$. densiflora has glabrous ones. However, all 15 specimens of $M$. caudata that we checked had completely glabrous filaments. A color photograph of $M$. densiflora's type is available at http://www.botany.si.edu/types.

\section{Acknowledgements}

The "Mel Names" project was funded by seed money from the "Electronic Catalogue of Names of Known Organisms" project organized by GBIF International 2005. We thank Werner Greuter for his advice and R. D. Stone for his careful review of our manuscript.

\section{References}

Cogniaux CA (1891) Melastomataceae. In: De Candolle A, De Candolle C (Eds) Monographiae Phanerogamarum, vol. 7. G. Masson, Paris, 1-1256.

Goldenberg R (2000) O gênero Miconia Ruiz \& Pav. (Melastomataceae). I. listagens analíticas, II. Revisão taxonômica da seção Hypoxanthus (Rich. ex DC.) Hook. F. PhD Thesis, Universidade Estadual de Campinas, Brazil.

Goldenberg R, Reginato M (2006) Sinopse da família Melastomataceae na Estação Biológica de Santa Lúcia (Santa Teresa, Espírito Santo). Boletim do Museu de Biologia Mello Leitão - Nova Série 20: 33-58.

Herzog T (1910) Pflanzenformationen Ostbolivias. Botanische Jahrbücher für Systematik, Pflanzengeschichte und Pflanzengeographie 44: 346-405.

Melastomataceae.net: a site with information on the biodiversity of Melastomataceae. http:// www.melastomataceae.net. 